\title{
Functional response of Phytoseiulus macropilis under different Tetranychus urticae (Acari: Phytoseiidae, Tetranychidae) population density in laboratory
}

\author{
Noeli Juarez Ferla1,3; Marla Marchetti; Liana Johann¹ \& Claus Haetinger² \\ ${ }^{1}$ Museu de Ciências Naturais, Centro Universitário UNIVATES. Rua Avelino Tallini 171, Caixa Postal 155, \\ 95900-000 Lajeado, RS, Brazil. \\ 2 Programa de Pós-graduação em Ambiente e Desenvolvimento, Centro Universitário UNIVATES. Avenida Avelino Tallini 171, \\ 95900-000 Lajeado, RS, Brasil. \\ ${ }_{3}^{3}$ Corresponding author. E-mail: njferla@univates.br
}

\begin{abstract}
We tested the functional response of the phytoseiid predator Phytoseiulus macropilis (Banks, 1904) to different population densities of Tetranychus urticae Koch, 1836 (the two-spotted spider mite - TSSM) in the laboratory. We evaluated the curve that best fits the data obtained, based on the reduced $\mathrm{X}^{2}$. The predators were obtained from leaves of Oso Grande strawberries at the municipality of Bom Princípio, state of Rio Grande do Sul, Brazil. Fifteen seemingly healthy females of $P$. macropilis were randomly chosen and individualized in each of the arenas with different TSSM densities. The following prey densities were tested: $1,2,3,5,10,20,30,35,45,55,70$ and 125 females. The tests were performed in a germination chamber with photoperiod of 12 hours at $28 \pm 1^{\circ} \mathrm{C}$ per day and $22 \pm 1^{\circ} \mathrm{C}$ at night and 80 $\pm 5 \%$ relative humidity. In all tests with up to three prey items, $P$. macropilis showed low functional response, whereas higher rates were observed when more prey items were offered. There was a strong positive correlation between increased prey numbers and daily prey consumption $(r=0.84$ and $p=0.0006)$. A significant correlation was found between prey consumption and total oviposition $(r=0.70, p=0.01)$. The daily oviposition rate was lower when few prey items were offered, increasing significantly with increased prey availability. The results showed a positive correlation between the number of prey items offered to the predator and its oviposition rate $(r=0.66, p=0.01)$. Nevertheless, a strong correlation was observed between the daily consumption of prey and eggs/female/day $(r=0.92, p<0.0001)$. A shorter oviposition period was reported when up to three prey items were offered. The oviposition period and the increase in prey numbers were positively correlated $(r=0.30, p=0.34)$, but the difference was not statistically significant. Nevertheless, the longer the egg-laying period, the greater the oviposition rate $(r=0.90, p<0.0001)$. The curve that best fits the data obtained in each case was also calculated, based on the least square method.
\end{abstract}

KEY WORDS. Biological control; bioecology; strawberry; two-spotted spider mite; curve adjust.

Strawberry (Fragaria sp., Rosaceae), considered one of the most important small fruits, is widely distributed all over the world, especially in temperate countries. In Brazil, particularly in the southern region, where large contingents of families work on strawberry plantations, this crop is very important to small and average producers.

Several different pests attack strawberry, including insects and mites. Among the latter, the Tetranychidae is the most economically important, featuring Tetranychus urticae Koch, 1836 (two-spotted spider mite - TSSM) as its key pest in Brazil and other regions of the world (Moraes \& Flechtmann 2008, SATO et al. 2002, WIsoki 1985). The TSSM is polyphagous, feeding on more than 600 plant species (Boland et al. 1998). It preferentially attacks the underside of developed leaves, spinning webs and causing silvery-white patches. Infestation by the TSSM initially causes chlorotic areas to appear on the upper surface of leaves. With time, the foliage bronze, dry out, and finally the leaves drop off the plants (FLechtmann 1979). The TSSM arises chiefly on the fructification period and harvest time (CAlZA \& Suplicy 1967) and may reduce the quantity and quality of the fruit yield (SANCES et al. 1982).

The TSSM is most effectively controlled with mitecides. Consumers tend to oppose this method because these insecticides are very toxic and farmers often fail to respect the grace period after spraying. As an alternative, several studies have shown that phytoseiid mites can control strawberry infestations by the TSSM efficiently. In Europe and in the United States, Phytoseiulus persimilis Athias-Henriot, 1957 effectively controlled the TSSM on strawberry (SimMONDS 1971, OATMANN et al. 1976, 1977a, OAtMan \& McMurtry 1966). Furthermore, this 
species has been released in Southern California to control tetranychids on several crops, and mass release of Neoseiulus californicus (McGregor, 1954) has significantly reduced TSSM populations on strawberry (Strong \& CRoft 1995, MCMurtry \& Croft 1997), and mass release has significantly reduced the TSSM population (OAtmann et al. 1977a,b). Phytoseiulus macropilis Banks, 1904 is a phytoseiid commonly associated with tetranychid populations in Brazil. It occurs naturally on strawberry in the South and Southeast regions of the country (Garcia \& Chiavegato 1997, Ferla et al. 2007) and has been shown to reduce populations of the TSSM on strawberry under greenhouse conditions (Oliveira et al. 2009).

So far, few data on phytoseiid functional responses have been evaluated, although several members of the family have been recognized as a predator of phytophagous orchard mites.

Despite their usefulness as predators of phytophagous orchard mites, phytoseiid mite functional responses have been seldom evaluated. Upon investigating the functional response of Typhlodromus occidentalis Nesbitt, 1951 predating on the TSSM, СHANт (1961) obtained a curve that has been interpreted as a linear rise to a plateau (Holing 1961). Mori \& Chant (1966) tested how $P$. persimilis responds to various densities of TSSM, finding that the consumption of adult prey per predator rose with increasing prey density, but significantly decreased after prey densities peaked. BADII \& MCMURTRY 1988 found that daily prey consumption and oviposition rates of Phytoseiulus longipes Evans, 1958 increased with increased densities of Tetranychus pacificus McGregor, 1919. Similar results were obtained by SANDNESS \& MCMurTRY (1970), who found that the number of prey killed daily by Amblyseius largoensis (Muma, 1955), Euseius concordis (Chant, 1959) and Typhlodromus floridanus Muma, 1955 accelerated with increasing densities of the prey Oligonychus punicae (Hirst, 1926).

Phytoseiulus macropilis has already shown a potential in locating and reducing populations of the TSSM under greenhouse conditions. However, nothing is known about its functional response in the presence of different population densities of this herbivorous mite. Here, we tested the functional response of $P$. macropilis in the presence of different densities of TSSM populations in the laboratory and also evaluated the curve that best fits the obtained data, based on the least square method and the reduced Chi-squared.

\section{MATERIAL AND METHODS}

This study took place at the acarology laboratory of the Museu de Ciências Naturais at Centro Universitário UNIVATES, Lajeado, Rio Grande do Sul, Brazil. The units of $P$. macropilis rearing stocks were kept as described by McMurtry \& SCRIVEN (1965) for P. persimilis. Each unit consisted of a wet sponge inside a tray partially covered with a cardboard. Predators were obtained two months before the beginning of the experiment, from leaflets of the Oso Grande strawberry variety collected at the municipality of Bom Princípio. They were fed with a mix- ture of different stages of the two-spotted spider mite, on the abaxial face of strawberry leaflets that had their edges covered with moistened cotton wool strips. The TSSM colonies were also kept in the laboratory, on similar strawberry leaflets arenas colonized by mites brought from field strawberries.

The rearing unities of TSSM and $P$. macropilis were maintained in different chambers at $25 \pm 1^{\circ} \mathrm{C}, 12$ hours photophase and $80 \pm 5 \%$ relative humidity.

Circles of $2.5 \mathrm{~cm}$ in diameter were cut from the strawberry leaflets and placed in un uncovered Petri dishes (3.5 x 1 $\mathrm{cm}$ ) containing distilled water, with the adaxial face up. The circle was held at the center of the dish by a pin attached to the base by a silicone drop. The water level was monitored daily and, whenever necessary, water was added to maintain its level at the base of the circle.

Fifteen apparently healthy $P$. macropilis females were randomly taken from a rearing unit with a paint brush and individualized in each of the arenas with different densities of TSSM. The following prey densities were tested for the study: 1, 2, 3, $5,10,20,30,35,45,55,70$ and 125 females. The numbers of prey consumed and eggs laid were counted every 24 hours. During this time, dead prey and predator eggs were removed. The TSSM eggs were also removed, and the females consumed by the predator were replaced to maintain the treatment density. The arena was changed every four days and the study ended when the female predator died. The tests were performed in a germination chamber with a photoperiod of 12 hours and $80 \pm$ $5 \%$ relative humidity, and the temperature was maintained at $28 \pm 1^{\circ} \mathrm{C}$ during the day and $22 \pm 1^{\circ} \mathrm{C}$ at night, which are values similar to those found in natural conditions. The statistical program BioEstat 5.0 was used to compare the means through the Tukey test, the correlation analysis and the adjustment of curves, at a significance level of 5\%. Oviposition and longevity periods were transformed in square root values for comparative statistical analysis.

\section{RESULTS}

The functional response of the predator P. macropilis was low in all tests with up to three prey items, whereas higher rates were observed when prey numbers increased (Tab. I). The predator did not consume all prey in the treatments, even when only one prey item was offered per day. There was a strong positive correlation between increased prey numbers and daily prey consumption $(\mathrm{r}=0.84, \mathrm{p}=0.0006)$. The lowest consumption was observed when only five or fewer prey items were offered to the predator. The highest prey consumption was observed when 125 items were offered. According to the value of the coefficient of determination, it appears that the logarithmic regression $\left(R^{2}=0.90\right)$ is the curve that best fits the data obtained (Fig. 1).

The lowest number of eggs/female was obtained when up to three prey items were offered per day. The oviposition rate increased when 30 and 45 prey items were offered, with 
Table I. Functional response (mean \pm SD) of $P$. macropilis in presence different density of $T$. urticae at $25 \pm 1{ }^{\circ} \mathrm{C}, 12$ hours photophase and $80 \pm 5 \%$ relative humidity. In the same column, means followed by the same letter do not show difference at a significance level of $5 \%$.

\begin{tabular}{cccccc}
\hline Prey/day & Prey/consumed/day & Eggs/female & Eggs/female/day & Longevity & Laid (days) \\
\hline 1 & $0.48 \pm 0.3 \mathrm{a}$ & $2.00 \pm 1.40 \mathrm{a}$ & $1.10 \pm 0.22 \mathrm{a}$ & $5.88 \pm 8.00 \mathrm{a}$ & $1.51 \pm 1.30 \mathrm{a}$ \\
2 & $0.82 \pm 0.4 \mathrm{a}$ & $8.50 \pm 7.20 \mathrm{a}$ & $1.57 \pm 0.47 \mathrm{ab}$ & $5.70 \pm 5.69 \mathrm{a}$ & $3.68 \pm 4.52 \mathrm{ab}$ \\
3 & $1.13 \pm 0.6 \mathrm{ab}$ & $6.20 \pm 5.50 \mathrm{a}$ & $1.98 \pm 0.75 \mathrm{ab}$ & $4.40 \pm 2.17 \mathrm{a}$ & $2.21 \pm 2.14 \mathrm{a}$ \\
5 & $1.25 \pm 0.9 \mathrm{ab}$ & $23.50 \pm 18.60 \mathrm{c}$ & $2.08 \pm 0.46 \mathrm{abc}$ & $13.50 \pm 9.30 \mathrm{a}$ & $7.65 \pm 7.53 \mathrm{bc}$ \\
10 & $1.02 \pm 0.4 \mathrm{ab}$ & $22.07 \pm 21.40 \mathrm{bc}$ & $2.09 \pm 0.86 \mathrm{abc}$ & $13.35 \pm 15.40 \mathrm{a}$ & $4.56 \pm 7.40 \mathrm{bc}$ \\
20 & $1.67 \pm 0.6 \mathrm{ab}$ & $24.60 \pm 21.07 \mathrm{c}$ & $2.45 \pm 0.72 \mathrm{bc}$ & $10.00 \pm 8.41 \mathrm{a}$ & $6.02 \pm 7.41 \mathrm{bc}$ \\
30 & $1.89 \pm 0.7 \mathrm{bc}$ & $29.13 \pm 21.83 \mathrm{c}$ & $2.79 \pm 0.69 \mathrm{c}$ & $12.13 \pm 10.76 \mathrm{a}$ & $6.47 \pm 6.95 \mathrm{bc}$ \\
35 & $1.82 \pm 0.8 \mathrm{bc}$ & $23.64 \pm 25.60 \mathrm{c}$ & $2.67 \pm 0.83 \mathrm{c}$ & $8.06 \pm 7.81 \mathrm{a}$ & $4.60 \pm 7.98 \mathrm{bc}$ \\
45 & $1.92 \pm 0.4 \mathrm{bc}$ & $28.06 \pm 19.70 \mathrm{c}$ & $2.60 \pm 0.95 \mathrm{bc}$ & $10.06 \pm 6.70 \mathrm{a}$ & $7.78 \pm 6.39 \mathrm{c}$ \\
55 & $1.78 \pm 0.7 \mathrm{bc}$ & $19.46 \pm 20.91 \mathrm{bc}$ & $2.35 \pm 0.53 \mathrm{abc}$ & $7.53 \pm 6.88 \mathrm{a}$ & $5.43 \pm 6.90 \mathrm{bc}$ \\
70 & $1.80 \pm 0.5 \mathrm{bc}$ & $26.28 \pm 20.23 \mathrm{c}$ & $2.78 \pm 0.79 \mathrm{c}$ & $8.13 \pm 5.76 \mathrm{a}$ & $6.48 \pm 5.45 \mathrm{bc}$ \\
125 & $2.47 \pm 0.8 \mathrm{c}$ & $18.78 \pm 16.80 \mathrm{bc}$ & $2.74 \pm 0.96 \mathrm{c}$ & $6.85 \pm 5.55 \mathrm{a}$ & $4.87 \pm 5.06 \mathrm{bc}$ \\
\hline
\end{tabular}

29.13 and 28.06 eggs/female, respectively. These results indicate a positive correlation between prey numbers and oviposition, but the difference was not statistically significant $(r=0.36$, $\mathrm{p}=0.24)$. Given the values of the coefficient of determination, it appears that the exponential association $\left(\mathrm{R}^{2}=0.79\right)$ is the curve that best fits the interaction between prey offered and total oviposition (Fig. 2). However, when the consumption of prey is correlated with the total oviposition, there is a significant correlation $(r=0.70, p=0.01)$, indicating that the consumption influences the ovipositon of this predator.

The daily oviposition rate of $P$. macropilis was lower when fewer prey items were offered and increased significantly with increased prey offer. Our results showed a positive correlation between the number of prey offered and an increase in the ovipositon rate $(\mathrm{r}=0.66, \mathrm{p}=0.01)$. The values of the coefficient of determination reveal that the opposite of hyperbole $\left(\mathrm{R}^{2}=0.91\right)$ is the curve that best fits the interaction between prey offered and eggs/female/day (Fig. 3). Nevertheless, a strong correlation was observed between the daily consumption of prey and eggs/female/day $(\mathrm{r}=0.92, \mathrm{p}<0.0001)$, indicating that increased prey consumption increases the number of eggs, leveling off at about three eggs/female/day.

There were no significant differences in the longevity of P. macropilis female when exposed to different prey numbers. Furthermore, there was a weak negative correlation between longevity and increased prey numbers $(\mathrm{r}=-0.12, \mathrm{p}=0.68)$ and a weak positive correlation between longevity and prey consumption $(\mathrm{r}=0.14, \mathrm{p}=0.65)$. The values of the coefficient of determination reveal that the exponential association $\left(\mathrm{R}^{2}=\right.$ 0.28 ) is the curve that best fits the data obtained in the interaction between prey/day and longevity (Fig. 4). However, a positive correlation was observed when the longevity was corre- lated with eggs per female $(r=0.72, p=0.007)$. It was also observed that a higher prey concentration tends to decrease the survival rate of the predator.

A shorter oviposition period was reported when up to three prey items were offered. The egg-laying period and the increase in prey numbers had positive correlation $(\mathrm{r}=0.30, \mathrm{p}=$ $0.34)$, but without a significant difference. Given the values of the coefficient of determination $\left(\mathrm{R}^{2}=0.54\right)$, it appears that the exponential association is the curve that best fits the data obtained, and that the egg-laying period reaches almost eight days (Fig. 5). Nevertheless, the longer the egg-laying period, the higher the oviposition rate $(\mathrm{r}=0.90, \mathrm{p}<0.0001)$.

\section{DISCUSSION}

In this study, P. macropilis demonstrated a positive functional response (increases prey consumption) when prey numbers were greater. All indices evaluated have shown that $P$. macropilis was unable to control the TSSM efficiently when population numbers were low and possibly to keep itself in an environment with low populations. Biological control by this predator is more efficient when five or more prey items are present at a given time. Phytoseiulus Evans, 1952 species are considered specialist predators associated with spider mites of Tetranychus Dufour, 1832 and have a web structure characterized by highly dense, complicated, irregular web where they lay their eggs, and release their feces and exuviae (MCMurTRy \& Croft 1997). Mori \& Chant (1966) observed that the predation rates of $P$. persimilis decreased in the presence of low (one or two prey items) or high (32 prey items) TSSM densities. According to the same authors, the contact between predatorprey occurs more often when prey numbers are high, but the 

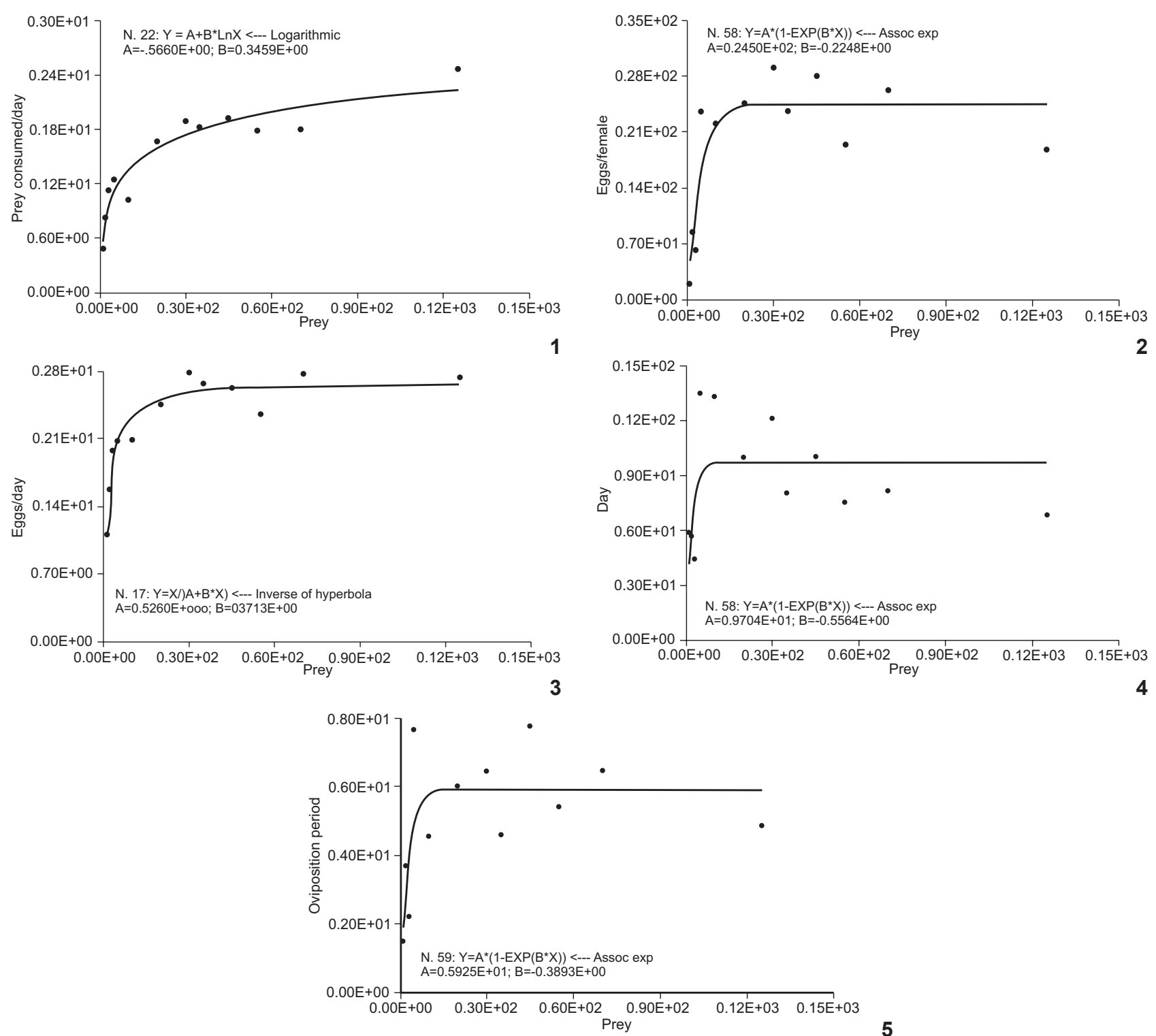

Figures 1-5.Curve fitting of the functional response and Pearson correlation of $P$. macropilis in presence of different density of T. urticae at $25 \pm 1{ }^{\circ} \mathrm{C}, 12$ hours photophase and $80 \pm 5 \%$ relative humidity: (1) prey consumed/day; (2) eggs/female; (3) oviposition days; (4) longevity; (5) oviposition period.

predation rate is reduced. The same happened with $P$. longipes: the daily consumption and oviposition rates increased with increasing densities of $T$. pacificus and the reproductive response (eggs per female predator per day) generally reflected the functional response curve, except at low prey densities (BADII \& MCMurtry 1988).

The data obtained in this work agree with the results of SANDNEss \& MCMurtry (1970), who observed that A. largoensis and $E$. concordis showed higher predation rates in treatments with greater numbers of prey. Typhlodromus floridanus showed higher predation rates in arenas with 10 to 125 prey items, and all species tested in that study presented lower predation in the presence of 1,2 or 5 prey items.

The reproductive success of Phytoseiulus species depends on the presence of tetranychid mites, and is more efficient when they belong to the genus Tetranychus. Species of Phytoseiulus have a strong potential to reach high population densities, laying an average of four eggs per day. They showed high prey 
consumption rate when compared with species of other genera(McMurtry \& Croft 1997). According to Sandness \& MCMurTry (1970), the oviposition rate of T. floridanus is higher than that of A. lagoensis and E. concordis. In arenas with five or more prey items, $T$. floridanus laid two eggs/female/day in average, whereas other predators laid 1.5 eggs/female/day. In this study, the highest rate was three eggs a day. Some factors such as the age of the females and the substrate where the prey fed may have influenced the results; furthermore, it is possible that the strain of $P$. macropilis used by us has a low reproductive rate. Also, the rate of increase of $P$. persimilis densities may vary according to the plant fed to the prey (McMurTry \& CROFT 1997).

The predatory mite $P$. persimilis is widely used to control the TSSM in greenhouses (PeTIT \& KARAN 1991) and was successfully demonstrated to work on a large scale strawberry crop plantation in southern California (OATMANn et al. 1977a, PORT 1981). Our results show that $P$. macropilis has oviposition and development rates similar to those of $P$. persimilis (Zhang 1995), being able to multiply rapidly and to succeed in the control of Tetrancyhus species. It can be used in biological control programs in Brazil because it is a native species. Furthermore, the technology for mass rearing this species is already known. However, precautions must be taken because this species is more efficient when released in environments with at least five prey items.

\section{ACKNOWLEDGMENTS}

We thank the Secretary of Science and Technology of Rio Grande do Sul (SC\&T/RS) and UNIVATES, University Center for the financial support of the project and the anonymous referees for suggestions and comments to the manuscript. We also thank Samuel F. Johann for his help in translating the manuscript into English.

\section{LITERATURE CITED}

Badi, M.H. \& J.A. McMurtry. 1988. Effect of prey density on functional and reproductive responses of the predatory mite Phytoseiulus longipes (Acari: Phytoseiidae). International Journal of Acarology 14: 61-69.

Bolland, H.R.; J. GutierRez \& C.H.W. Flechtmann. 1998. World catalogue of the spider mite family (Acari: Tetranychidae). Leiden, Köln Brill.

Calza, R. \& N. Suplicy. 1967. Estudos sobre o "ácaro do morangueiro" Tetranychus telarius (L.). Biológico 33: 137-143.

Chant, D.A. 1961. The effect of prey density on prey consumption and oviposition in adults of Typhlodromus (T.) occidentalis Nesbitt (Acarina: Phytoseiidae) in the laboratory. Canadian Journal of Zoology 39: 311-315.

Ferla, N.J.; M.M. Marchetti \& D. Gonçalves. 2007. Ácaros predadores (Acari) associados à cultura do morango (Fragaria sp., Rosaceae) e plantas próximas no Estado do Rio Grande do Sul. Biota Neotropica 7 (2): 1-8.

Flechtmann, C.H.W. 1979. Ácaros de importância agrícola.
São Paulo, Livraria Nobel S.A, 189p.

Garcia, I.P. \& L.G. Chiavegato. 1997. Resposta funcional e reprodutiva de Phytoseiulus macropilis (Banks, 1905) (Acari: Phytoseiidae) a diferentes densidades de ovos de Tetranychus urticae (Koch, 1836) (Acari: Tetranychidae). Científica 25 (1): 35-43.

HolLING, C.S. 1961. Principles of insect predation. Annual Review of Entomology 6: 163-182.

McMurtry, J.A. \& G.T. Scriven. 1965. Insectary production of phytoseiid mites. Journal of Economic Entomology 58: 282-284.

McMurtry, J.A. \& A.B. Croft. 1997. Life-styles of Phytoseiidae mites and their roles in biological control. Annual Review of Entomology 42: 291-321.

Moraes, G.J. de \& C.H.W. Flechtmann. 2008. Manual de Acarologia: Acarologia básica e ácaros de plantas cultivadas no Brasil. Ribeirão Preto, Holos Editora, 308p.

Mori, H. \& D.A. Chant. 1966. The influence of prey density, relative humidity and starvation on the predacious behavior of Phytoseiulus persimilis Athias-Henriot (Acarina: Phytoseiidae). Canadian Journal of Zoology 44: 483-491.

OAtManN, E.R. \& J.A. McMurtry. 1966. Biological control of the twospotted mite on strawberry in Southern California. Journal of Economic Entomology 59: 433-439.

Oatmann, E.R.; F.E. Gilstrap \& V. Voth. 1976. Effect of different release rates of Phytoseiulus persimilis (Acarina: Phytoseiidae) on the twospotted spider mite on strawberry in Southern California. Entomophaga 21 (3): 269-273.

Oatmann, E.R.; J.A. McMurtry; F.E. Gilstrap \& V. Voth. 1977a. Effect of releases of Amblyseius californicus, Phytoseiulus persimilis and Typhlodromus occidentalis on the twospotted spider mite on strawberry in Southern California. Journal of Economic Entomology 70 (1): 45-47.

Oatmann, E.R.; J.A. McMurtry; F.E. Gilstrap \& V. Voth. 1977b. Effect of releases of Amblyseius californicus on the twospotted spider mite on strawberry in Southern California. Journal of Economic Entomology 70 (1): 638-640.

Oliveira, H; M.A.M. Fadini; M. Venzon; D. Rezende \& A. Pallini. 2009. Evaluation of the predatory mite Phytoseiulus macropilis (Acari: Phytoseiidae) as a biological control agent of the twospotted spider mite on strawberry plants under greenhouse conditions. Experimental \& Applied Acarology 47: 275-283.

PetrT, F. L. \& D. J. Karan. 1991. Influence of pesticide treatments on consumption of Tetranychus urticae (Acarina: Tetranychidae) eggs by Phytoseiulus persimilis (Acarina: Phytoseiidae). Entomophaga 36 (4): 539-545.

PorT, C.M \& N.E.A. SCOPES. 1981. Biological control by predatory mites (Phytoseiulis persimilis Athias-Henriot) of red spider mite (Tetranychus urticae Koch) infesting strawberries grown in "walk-in" plastic tunnels. Plant Pathology 30: 95-99.

Sances, F. V.; N.C. Toscano; L.F. LaPre; E.R. Oatmann \& M.W. JoHnson. 1982. Spider mites can reduce strawberry yields. California Agriculture 36: 15-16. 
SAndness, J.N. \& J.A. McMurtry. 1970. Functional response of three species of Phytoseiidae (Acarina) to prey density. Canadian Entomologist 102: 692-704.

Sato, M.E.; M. Silva; L.R. Gonçalves; M.F. Souza Filho \& A. Raga. 2002. Toxicidade diferencial de agroquímicos a Neoseiulus californicus (McGregor) (Acari: Phytoseiidae) e Tetranychus urticae Koch (Acari: Tetranychidae) em morangueiro. Neotropical Entomology 31: 449-456.

SIMMONDS, S.P. 1971. Observations on the possible control of Tetranychus uticae on strawberries by Phytoseiulus persimilis. Plant Pathology 20: 117-119.
Strong, W.B. \& B.A. Сroft. 1995. Inoculative release of phytoseiid mites (Acarina: Phytoseiidae) into the rapidly expanding canopy of hops for control of Tetranychus urticae (Acarina: Tetranychidae). Environmental Entomology 24: 446-453.

WisoKI, M. 1985. Other outdoor crops, p. 375-384. In: W. Helle \& M.W. Sabelis (Eds). Spider Mites: Their Biology, Natural Enemies and Control. Amsterdam, Elsevier, vol. 1B, 458p. ZHANG, Z.Q. 1995. Variance and covariance of ovipositional rates and developmental rates in the Phytoseiidae (Acari: Mesostigmata): a phylogenetic consideration. Experimental \& Applied Acarology 19: 139-146.

Submitted: 03.V.2010; Accepted: 19.IX.2010.

Editorial responsibility: Pedro Gnaspini 